\title{
Hate Speech by Twitter Netizens Against President Joko Widodo During the Covid-19 Pandemic (Forensic Linguistics Study)
}

\author{
Dedy Isnanto*, Dr. Teguh Setiawan** \\ dedyisnanto.2020@student.uny.ac.id*, teguh.setiawan@uny.ac.id** \\ Language and Arts Education, Yogyakarta State University, Indonesia \\ DOI: 10.29322/IJSRP.11.09.2021.p11746 \\ http://dx.doi.org/10.29322/IJSRP.11.09.2021.p11746
}

\begin{abstract}
Twitter social media is heavily colored by various wild post that are not clear and contain hate speech. During this Covid19 pandemic, many of President Jokowi's government policies have drawn contra. The freedom to make uplouds is used by Twitter netizens to criticize the government. The problem is that many people uploud criticism with hate speech. This paper aims to describe the language contained in uplouds that contain hate speech, then slow what uplouds include hate speech and what kind of uplouds have a criminal impact. The method used is descriptive qualitative. The data source us is Twitter. The object of the study is the meaning of the discourse of uplouding hate speech. The data collection methed used is the continuous listening technique with advanced techniques, namerly the free listening technique, the conversational technique and the note-taking technique. The author uses the study of forensic linguistics and statutory law. The result of this study include: (a) the data is indentified as hate speech and has a criminal impact, (b) the data is indetified as hate speech but does not have a criminal impact, (c) the data identified does not contain elements of hate speech and does not contain crime.
\end{abstract}

Index Terms- Hate Speech, Twitter, Covid-19 Pandemic

\section{Introduction}

The Indonesian people were surprised by the emergence of a new disease named Covid-19. The disease originated in the city of Wuhan, in China. Not long after, Covid-19 spread various countries and infects citizens in those countries.

Covid-19 continues to be a topic of discussion for the world community, including Indonesian. On March 2, 2020, President Joko Widodo and Terawan Agus Putranto, who was then Minister of Health, announced the first case of Covid-19 in Indonesian. Two people have been declared positive for Convid-19. Both had contact with Japanese citizens who came to Indonesian. Since then, Covid-19 cases in Indonesian have continued to grow and grow and to this day, based on information on the development of Covid-29 cases from the Indonesian Ministry of Health on August 10, 2021, there have been more than 3,718,821 positif Covid-19 cases, 3,171,147 have been declared cured, and 110,619 died. Along with this, the Indonesian govenment has implemented various policies to reduce the number of Covid-19 cases in Indonesian. Starting from PSBB policy (Large-Scale Social Restrictions) in April to June 2020, Transitional PSBB in June to September 2020, Strict PSBB in September to October 2020, Transitional PSBB 2 in October 2020 to January 2021, PPKM (Enforcement of Restrictions on Community Activities) from January to February 2021, Micro PPKM from February to June 2021, Emergency PPKM from 1 to 20 July 2021, and PPKM Level 3-4 from 21 to 25 July 2021. These various govenment policies have reaped many benefits. Cons of the Indonesian people, especially the Twitter netizens. The counter stance was expressed throught policies social media Twitter. The on going Covid-19 pandemic and various government policies that are considered to be increasingly difficult for the community, especially people with lower middle class economies, have made Twitter netizens write uplouds as a form protest or anger against the government, especially President Joko Widodo. But unfortunately, the protests and forms of anger that were poured out through Twitter social media contained many hate speeches against President Joko Widodo. Moving on from this problem, this study tries to show (1) what kind of uplouds are classified as hate speech, and (2) what kind of hate speech uplouds can have legal or criminal consequences.

According to Koncaver (2013: 675) hate speech is words that encourage hatred, which can be described as racist, religious discrimination, xenophobia, homophobic, transphobic, heterosexual, ethnic nationalist, awareness of social status, awareness of economic status, and discrimination according to their disability, problems health, dress styles and the sports teams they support are the dominant ideological discourse, sometimes overtly and sometimes in covert ways. Meanwhile, the concept of hate speech according to the European Council of Ministes Committee is that the term hate speech must be understood to include all forms of expression that spread, incite, promote or justify racial hatred, xenophobia, anti-semitism or other forms or hatred based on intolerance.

Hate speech in Indonesian is regulated in several legal bases which include Articles 156 and 157 of the Criminal Code regulating offenses that spread hatred, hostility or humiliation between or against groups of the Indonesian people, then Law Number 12 of 2005 concerning Ratification of the International Covenant on Human Rights. Civil and Political, Law Number 
40 of 2008 concerning the Elimination of Racial and Ethnic Discrimination, Article 4 letter b prohibits people from showing hatred or hatred towards people because of racial and ethnic differences, either in writing or in pictures, speech or symbols. In public, Law of the Republic of Indonesian Number 19 of 2016 concerning Amendments to Law Number 11 of 2008 concerning ITE which reads about the prohibition of hate speech as reffered to in Article 28 paragraph 2 and Article 45 paragraph 2, and Law Number 9 of 1988 concerning Independence Expressing opinions in public containing hate speech offenses.

Massive uplouds of hate speech against President Joko Widodo is a phenomenon that should not be allowed to go unpunished. Therefore, there needs to be an educational effort for social media activists so that they can understand utterances that can have legal implications. The reason for the many hateful uplouds is the disagreement of some people with the policies taken by the government to reduce the number of Covid-19 cases in Indonesian. Forensic linguistics is a linguistics discipline consisting of two combinations of disciplines, namely linguistics and law (Coulthard and Johnson, 2010; Gibbons and Turell 2008). There are three objects of forensic linguistics study, namely language in legal products, language in legal proceedings, and language in legal evidence. This study seeks to educate the public about hate speech and provide awareness about the legal repercussions that will be obtained. In the analysis of the text, hate speech is directed into the object of language in legal evidence. The language analysis used in this study is a critical discourse analysis knife, while the legal language uses several rules related to hate speech. Critical discourse analysis is used as a scalpel for a text that contains hate speech.

This study applies the critical discourse analysis model of Norman Fairclough (1989). Norman Fairclough (1989: 131132) provides a discourse analysis that describes the relevance of the text to the surrounding social enviroment. Text is a word or sentence that describes the object of the uploud, as well as explains the relationships between the defined objects, while the social environment is defined as a context outside the text that is able to influence how the discourse appears in the media (Fairclough in Eriyanto, 2001: 289-320). Text in Fairclogh's perspective can be described and analyzed through three elements, namely representation, relation, and identity. The explanation of these three elements is as follows.

Table 1. Norman Fairclough Text Analysis Model

\begin{tabular}{|l|l|}
\hline \multicolumn{1}{|c|}{ Element } & \multicolumn{1}{c|}{ Discourse You Want to Unravel } \\
\hline Representation & $\begin{array}{l}\text { How events, people, groups, situations, circumtances, or } \\
\text { anything are displayed and described in the text. }\end{array}$ \\
Relation & $\begin{array}{l}\text { How the relationship between the audience, and participans } \\
\text { is displayed is displayed and described in the text. }\end{array}$ \\
Identity & $\begin{array}{l}\text { How the identity of the auidence, and participants are } \\
\text { described in the text. }\end{array}$ \\
\hline
\end{tabular}

The legal bases used in this study are the Criminal Code (KUHP) and Law Number 11 of 2008 concerning ITE. The articles contained in the regulation are used as a reference in following up on a hate speech that has legal implications. The following is an explanation of the articles that regulate hate speech.

Table 2. Criminal Articles for Hate Speech

\begin{tabular}{|l|l|l|}
\hline $\begin{array}{l}\text { Criminal } \\
\text { Code }\end{array}$ & Article 156 & $\begin{array}{l}\text { Anyone who publicly expresses feelings of hostility, hatred, or } \\
\text { demeaning to one several groups of the Indonesian population, } \\
\text { shall be sentenced to a maximum imprisonment of four years or a } \\
\text { maximum fine of four thousand five hundred rupiah. What is meant } \\
\text { by a group in this article and the next article is any part of the } \\
\text { Indonesian population that has differences with one or several } \\
\text { other parts of the population based on ethnicity, region, religion, } \\
\text { origin, descent, nationality or position according to constitutional } \\
\text { law. }\end{array}$ \\
\hline
\end{tabular}




\begin{tabular}{|c|c|c|}
\hline $\begin{array}{l}\text { Crimial } \\
\text { Code }\end{array}$ & Article 156 a & $\begin{array}{l}\text { It shall be punished by a maximum imprisonment of five years, } \\
\text { whoevver intentionally in public expresses feelings or commits an } \\
\text { act: } \\
\text { 1. Which is essentially emmity, abuse or blasphemy against } \\
\text { a religion professed in Indonesia; } \\
\text { 2. With the intention that people do not adhere to any } \\
\text { religion that is based on God Almighty. }\end{array}$ \\
\hline $\begin{array}{l}\text { Criminal } \\
\text { Code }\end{array}$ & $\begin{array}{l}\text { Article } 156 \text { a } \\
\text { Paragraph } \\
\text { (1) }\end{array}$ & $\begin{array}{l}\text { Any person who broadcasts, displays or attaches a letter or picture, } \\
\text { the contens of which express feelings of hostility, hatred or } \\
\text { contempt among or against groups of the Indonesian population, } \\
\text { with the intention of making the letter or picture known to the } \\
\text { public, shall be sentenced to a maximum imprisonment of two } \\
\text { years and six months or a maximum fine of four thousand five } \\
\text { hundred rupiah. }\end{array}$ \\
\hline $\begin{array}{l}\text { Criminal } \\
\text { Code }\end{array}$ & $\begin{array}{l}\text { Article } 156 \text { a } \\
\text { Paragraph } \\
\text { (2) }\end{array}$ & $\begin{array}{l}\text { If the guilty person commits the crime in his position and the time } \\
\text { of committing the crime, five years have not passed since his } \\
\text { previous sentence for a similar crime has also been determined, he } \\
\text { may be dismissed from his position. }\end{array}$ \\
\hline ITE Law & $\begin{array}{l}\text { Article } 28 \\
\text { Paragraph } \\
(2)\end{array}$ & $\begin{array}{l}\text { Everyone intentionally and without rights disseminates } \\
\text { information that is intended to cause hatred or hostility to certain } \\
\text { individuals and or groups of people based on ethnicity, religun, } \\
\text { race and intergroup (SARA). }\end{array}$ \\
\hline ITE Law & $\begin{array}{l}\text { Article } 45 \text { A } \\
\text { Paragraph } \\
(2)\end{array}$ & $\begin{array}{l}\text { Everyone who fulfills the elements as referrend to in Article } 28 \\
\text { paragraph (1) or paragraph (2) shall be sentenced to a maximum } \\
\text { imprisonment of } 6 \text { (six) years and or a maximum fine of Rp. } \\
1.000 .000 .000 .00 \text { (one billion rupiah). }\end{array}$ \\
\hline
\end{tabular}

From the explanation above, hate speech can be interpreted as an act of language crime committed by spreading opinions to get support for hating other people or targets. Usually hate speech is echoed because the propagator does not agree or does not side with someone or something.

In Law Number 11 of 2008, Article 28 paragraph (2) and Article 45 A paragraph (2) are the rules used in cases of spreading SARA based hatred. In addition, there are also criminal rules in the Criminal Code and Law Number 40 of 2008 concerning the Elimination of Racial and Ethnic Discrimination. Currently, the articles contained in the ITE Law are much more effective in applying SARA based hate speech cases in cyberspace.

In Law Number 20 of 2008, especially Article 4 and Article 16, the core substance is hatred or hatred towards people because of racial and ethnic differences. Then, in the Criminal Code, articles related to the spread of hatred against groups/religions. Then, in Law Number 11 of 2008 concerning Information and Electronic Transactions, especially in Article 28 paragraph (2) there is also a core substance, namely causing hatred or hostility to certain individuals and/ or community groups based on ethnicity, religion, race and intergroup (SARA). This is different from the Law on Discrimination, the ITE Law uses elements of SARA associated with ethnicity, religion, race, and intergroup which show that its components are wider in scope. Currently Article 28 paragraph (2) ITE is the strongest article for criminal acts of hate speech cases that occur in cyberspace compared to other criminal articles. Broader elements will make this article more effective in the future because heavier and more specific criminal threats can ensnare suspects in hate speech cases in cyberspace. In monitoring the Institute for Criminal Justice Reform (ICJR), this article of the ITE Law has been used in various cases of hate speech that occured in Indonesian. Starting from the Sandy Hartono case in 2011, the Alexander Aan case in 2012, the Muhamad Rokhisun case in 2013, and the I Wayan Hery Christian case. The Institute for Criminal Justice Reform (ICJR) supports the more effective use of Article 28 paragraph (2) and Article 45 in the current situation.

The elements contained in Article 28 paragraph (2) must be complete and fulfilled in order to be able to ensnare the perpetrator with the punishment referred to in the article to be used. The following are the elements contained in Article 28 paragraph (2) :

a. Each person;

b. Intentionally and without rights;

c. Disseminate targeted information; 
d. To create feelings of hatred or hostility towards certain individuals and/ or community groups;

e. Based on ethnicity, religion, race and intergroup (SARA).

\section{Research Methodology}

The study method on hate speech by Twitter Netizens against President Joko Widodo during the Covid-19 pandemic is qualitative-descriptive (Science et al., 2017). The qualitative method in this study works to undestand the symptoms, events, facts, and realities that occur. In this case, the hate speech against President Joko Widodo that occurs on social media Twitter is a phenomenon that occurs in the midst of the reality of social life. The result of the qualitative study methodology are in the form of descriptive research studies. This study scientifically works to examine linguistics behavior which is then explained as a linguistic symptom that arises from science (Arinto, 2018: 116). Some things that can be described are the classification of hate speech uplouds, the determination of the law according to the relevant article.

The object of this scientific study the meaning of discourse about hate speech by Twitter Netizens against President Joko Widodo during the Covid-19 pandemic. Then, the data in this study is the meaning of discourse about hate speech against President Joko Widodo in Twitter social media. The data is a combination of the research object with the research object with the research context (Kesuma, 2007: 25). The location of this study is the virtual world. The virtual world in the form of social media Twitter as a place to obtain data. Furthermore, for the data collection method, this study uses the listening method followed by advanced techniques in the form of the Listening Free Libat Cakap technique and the Recording technique. The listening method can be used to obtain oral data, it can also be applied to obtain written data.

Analysis of the data obtained was carried out in two stages, namely critical discourse analysis and legislation. Norman Fairclough's (1989) critical discourse analysis theory was used to find out what kind of uplouds contain hate speech. Then, the determination of the law in hate speech refers to the legal rules that apply in Indonesian. The result of data analysis are then presented informally by paying attention to ordinary words, not by formula or rules that are symbols.

\section{Results and Discussions}

\section{a. Results}

The following are the findings of researchers ralated to hate speech by Twitter Netizens against President Joko Widodo during the Covid-19 pandemic. The results of this search are used as data samples which will then be analyzed using the discipline of forensic linguistics.

Table 3. List of uplouds that are considered to contain hate speech against President Joko Widodo on social media Twitter.

\begin{tabular}{|c|c|c|c|}
\hline $\begin{array}{c}\text { Number } \\
\text { Data }\end{array}$ & $\begin{array}{l}\text { Regarding } \\
\text { Uplouds }\end{array}$ & $\begin{array}{l}\text { Account Name } \\
\text { Uploader }\end{array}$ & $\begin{array}{l}\text { Uploads } \\
\text { Date }\end{array}$ \\
\hline 1 & $\begin{array}{l}\text { Even though it's in the form of a planga plongo, } \\
\text { and seems simple, it's hard for him to be removed } \\
\text { from his position, let alone ordered to give up. } \\
\text { Remember, he has a pet frog in his palace, don't } \\
\text { let him ask them to intervene, they can beat us. } \\
\text { \#MrPresidentGiveUp }\end{array}$ & @ labibbiib & 7 July 2021 \\
\hline 2 & $\begin{array}{l}\text { I rarely mess with government officials, but this is } \\
\text { really a big deal TOLOL. } \\
\text { The point is that the state doesn't want to feed the } \\
\text { people, that's why it uses the term PPKM. And } \\
\text { extend it a bit because there's no demo } \\
\text { everywhere. } \\
\text { It's been } 2 \text { years but it's getting worse. } \\
\text { KIRIK! }\end{array}$ & @ajikurr & $\begin{array}{lr}2 & \text { August } \\
2021 & \end{array}$ \\
\hline 3 & $\begin{array}{l}\text { The worst president in the history of the } \\
\text { Indonesian nation. @ jokowi } \\
\text { \#ActuallyJokowiIsFinished }\end{array}$ & @ BangCepot77 & 26 July 2021 \\
\hline 4 & $\begin{array}{l}\text { One fool who has power, will be able to subdue a } \\
\text { million smart people who serve power by making } \\
\text { all fools. }\end{array}$ & @abu_waras & $\begin{array}{l}10 \text { August } \\
2021\end{array}$ \\
\hline
\end{tabular}




\begin{tabular}{|c|c|c|c|}
\hline 5 & $\begin{array}{l}\text { \#KitaSambutJokowiTurun then after that we held } \\
\text { a grand recitation, in every city and district } \\
\text { throughout Indonesian. } \\
\text { To express gratitude to Allah SWT, for stopping } \\
\text { the most severe ordeal that has ever befallen the } \\
\text { Indonesian nation! }\end{array}$ & @Purnomo_Back & 27 July 2021 \\
\hline 6 & $\begin{array}{l}\text { What is the dream of this republic giving birth to } \\
\text { people like this, a government that is reckless and } \\
\text { incompetent to handle covid-19 of the accused } \\
\text { people, without shame } \\
\text { \#FassingoftheEmpathyoftheRuler }\end{array}$ & @MedanSoepriono & 28 July 2021 \\
\hline 7 & $\begin{array}{l}\text { Such is the mentality of assholes. Quality thinks a } \\
\text { pile of trash. It doesn't matter if the people don't } \\
\text { eat, the important thing is that they have. Their } \\
\text { trial in the hereafter will not be easy. } \\
\text { \#FassingoftheEmpathyoftheRuler }\end{array}$ & @ YakinBack & 28 July 2021 \\
\hline 8 & $\begin{array}{l}\text { PPKM } \\
\text { Planga Plongo Doesn't Think } \\
\text { Slowly We Die } \\
\text { Definitely Not Eating } \\
\text { \#JokowiMusibahBangsa } \\
\text { \#JokowiEndGame }\end{array}$ & @ @lalan69 & $\begin{array}{l}2 \\
2021\end{array}$ \\
\hline 9 & $\begin{array}{l}\text { You guys used to take this pandemic for granted. } \\
\text { Show your responsibility by resigning or } \\
\text { resigning, because you have failed... Now you are } \\
\text { oppressing the people to hide your stupidity... } \\
\text { \#Jokowi7YearsEnough } \\
\text { \#Jokowi7YearsEnough }\end{array}$ & @ Troy7112 & 7 July 2021 \\
\hline 10 & $\begin{array}{l}\text { Vaccine queues, train queues, congestion effects } \\
\text { from road closures etc. Is this a smart solution } \\
\text { which avoids problem after problem!? Work, } \\
\text { work, work..!! } \\
\text { You wory is messy. } \\
\text { \#Jokowi7YearsEnough }\end{array}$ & @ republikwayang & 6 July 2021 \\
\hline 11 & $\begin{array}{l}\text { God will not change the fate of a people if the } \\
\text { people do not want to change it. } \\
\text { Obviously, Prof. It is indeed the president stupid } \\
\text { policy that. } \\
\text { Must be changed to change the situation. } \\
\text { Please get your brain prof.. } \\
\text { Please! } \\
\text { \#WorstPresidentInHistory }\end{array}$ & @ JossBangJago & 30 July 2021 \\
\hline
\end{tabular}




\begin{tabular}{|c|c|c|c|}
\hline 12 & $\begin{array}{l}\text { No problem sir @ Jokowi just keep on extending it } \\
\text { until the Dajjal comes down, Imam Mahdi comes } \\
\text { down, Prophet Isa As descends, then the } \\
\text { apocalypse continues. }\end{array}$ & @BadraAppz & $\begin{array}{l}2 \text { August } \\
2021\end{array}$ \\
\hline 13 & $\begin{array}{l}\text { Bobrookk } \\
\text { Bobrookkkkk } \\
\text { @ Jokowi } \\
\text { Ancur the country } \\
\text { \#PakdeMenclaMencle } \\
\text { \#PakdeMenclaMencle }\end{array}$ & @ BadraAppz & 22 July 2021 \\
\hline 14 & $\begin{array}{l}\text { It's been a long time for a dog too @Jokowi, I } \\
\text { don't know the minister abroad, even if you sign } \\
\text { the permit process, you're an idiot, you have to } \\
\text { take it down, people }\end{array}$ & @BadraAppz & 4 July 2021 \\
\hline 15 & $\begin{array}{l}\text { You @ Jokowi is the most stupid leader, and the } \\
\text { most DZALIM to his people }\end{array}$ & @BadraAppz & 17 July 2021 \\
\hline 16 & $\begin{array}{l}\text { \#WorstPresidentInHistory } \\
\text { \#Don'tWait2024 } \\
\text { Just come down. It's not that bad. Criticized in the } \\
\text { right ear out the left ear. Was Given a warning, } \\
\text { called harassing. Yes, think about it. }\end{array}$ & @ aruinsan98 & 22 July 2021 \\
\hline 17 & $\begin{array}{l}\text { BREAKING NEWS } \\
\text { \#JokowiMusibahNation } \\
\text { Since there are not many who are suffering, then } \\
\text { PPKM is extended. } \\
\text { PPKM } \\
\text { Plonga Plongo Don't Think }\end{array}$ & $@$ Nafaradesign & $\begin{array}{l}2 \text { August } \\
2021\end{array}$ \\
\hline 18 & $\begin{array}{l}\text { You are the toughest test for us and the Indonesian } \\
\text { nation } \\
\text { \#JokowiMusibahNation }\end{array}$ & @ JasMiN192919 & $\begin{array}{ll}3 & \text { August } \\
2021 & \end{array}$ \\
\hline 19 & $\begin{array}{l}\text { Maybe for the GLOBAL ELITE } \\
\text { PPKM is the solution but for us it's an unclean pig } \\
\text { dog \#PPKM } \\
\text { C\#PresidenKagakNgartiLockDown } \\
\text { \#JokowiMusibahNation }\end{array}$ & @AhmadRisan16 & $\begin{array}{l}3 \text { August } \\
2021\end{array}$ \\
\hline 20 & $\begin{array}{l}\text { Tsunamis, Landslides, earthquakes, wedus } \\
\text { gembel, are indeed big disasters, but history will } \\
\text { record that Indonesian has experienced the biggest } \\
\text { disaster, which was led by someone who did not } \\
\text { have the capacity to lead a country. } \\
\text { \#JokowiMusibahNation }\end{array}$ & @ doyan & $\begin{array}{l}2 \text { Augsut } \\
2021\end{array}$ \\
\hline
\end{tabular}




\begin{tabular}{|c|c|c|c|}
\hline 21 & $\begin{array}{l}\text { The more you come here, the more stupid it gets. } \\
\text { When people scream the impact of the pandemic, } \\
\text { even thing that are not important take precedence. } \\
\text { He said the cost printing Rp. Billion... } \\
\text { Cheap, just increase taxes or taxes that have not } \\
\text { been taxed... } \\
\text { \#JokowiMusibahNation }\end{array}$ & @ tydofirenze & $\begin{array}{l}3 \quad \text { August } \\
2021\end{array}$ \\
\hline 22 & $\begin{array}{l}\text { Our toughest test is Mr. Honorable Mr. President } \\
\text { Joko Widodo, not the state... } \\
\text { The country will be fine, if it is brought by good } \\
\text { people. } \\
\text { \#JokowiMusibahNation }\end{array}$ & @kmlihsn & $\begin{array}{l}3 \text { August } \\
2021\end{array}$ \\
\hline 23 & $\begin{array}{l}\text { The deadly duet that tore the mouth } 2 \text { of the } \\
\text { tadpoles... } \\
\text { M.Nuh \& Akidi Tio } \\
\text { \#JokowiMusibahNation } \\
\text { \#JokowiMusibahNation }\end{array}$ & @BonsaiKalapa & $\begin{array}{l}2 \text { August } \\
2021\end{array}$ \\
\hline 24 & $\begin{array}{l}\text { No matter how stupid and stupid you are, there are } \\
\text { still more stupid idiots in this world.. } \\
\text { Thank God, from the start, I've never voted for } \\
\text { that crook.. } \\
\text { \#JokowiMusibahNation } \\
\text { \#JokowiMundurPeopleCongratulations } \\
\text { \#JokowiBelekok }\end{array}$ & @ Awaristo & $\begin{array}{l}3 \text { August } \\
2021\end{array}$ \\
\hline 25 & $\begin{array}{l}\text { The Indonesian people must be super patient in } \\
\text { accepting the calamity of getting a leader who } \\
\text { brought the dectruction of this country. } \\
\text { \#JokowiMusibahNation }\end{array}$ & @ Opposition009 & $\begin{array}{l}2 \quad \text { August } \\
2021\end{array}$ \\
\hline 26 & $\begin{array}{l}\text { All the chaos of this nation started from here... } \\
\text { \#GorongGorongAjaib } \\
\text { \#JokowiMusibahNation }\end{array}$ & @MAdemayem & $\begin{array}{l}3 \text { August } \\
2021\end{array}$ \\
\hline 27 & $\begin{array}{l}\text { Stupid Leader with no solution... } \\
\text { \#JokowiMusibahNation }\end{array}$ & @Man143Ladies & $\begin{array}{l}3 \text { August } \\
2021\end{array}$ \\
\hline 28 & $\begin{array}{l}\text { \#JokowiMusibahNation } \\
\text { Life is just a disaster.. so let's pray that there won't } \\
\text { be another disaster }\end{array}$ & @ MahfudinMahfu13 & $\begin{array}{l}3 \text { Agustus } \\
2021\end{array}$ \\
\hline 29 & $\begin{array}{l}\text { Who used to choose? Now how come you are the } \\
\text { most angry when PPKM is extended. Bngst } \\
\text { indeed. } \\
\text { \#JokowiMusibahNation }\end{array}$ & @ Idar45621484 & $\begin{array}{l}3 \text { Augus } \\
2021\end{array}$ \\
\hline 30 & $\begin{array}{l}\text { \#JokowiMusibahNation } \\
\text { Not only brings disaster to humans, mukidi also } \\
\text { brings disaster to Komodo dragons } \\
\text { \#PakdeMundurPlease }\end{array}$ & @_FarisAska_ & $\begin{array}{l}3 \text { August } \\
2021\end{array}$ \\
\hline
\end{tabular}




\begin{tabular}{|c|c|c|c|}
\hline 31 & $\begin{array}{l}\text { If you are hit by Jokowi, say innalillahi wainna } \\
\text { ilaihi rojiun... } \\
\text { \#JokowiMusibahNation }\end{array}$ & @james_abdillah & $\begin{array}{l}2 \\
2021\end{array}$ \\
\hline 32 & $\begin{array}{l}\text { The hastag immediately skyrocketed. } \\
\text { It's not because the economy is bad, but because } \\
\text { of the misfortune that Pakde becomes president, } \\
\text { he hasn't been able to properly manage his power. } \\
\text { Already, the meatballs have passed } \\
\text { \#JokowiMusibahNation }\end{array}$ & @ pokoknyaori & $\begin{array}{ll}2 & \text { August } \\
2021 & \end{array}$ \\
\hline 33 & $\begin{array}{l}\text { Does that mean that the Jokowi regime is the } \\
\text { results of thieves? } \\
\text { There's a problem with his brain... } \\
\text { \#PresidenFailedtobeReplaced }\end{array}$ & @ udafajri & 20 July 2021 \\
\hline 34 & $\begin{array}{l}\text { So it's clear that he has to back off! } \\
\text { The problem is he doesn't want to imitate Gusdur } \\
\text { Pak Mpud, he doesn't want to back down/ down } \\
\text { because he doesn't know himself } \\
\text { \#PresidenFailedtobeReplaced }\end{array}$ & @ genth5789 & 5 July 2021 \\
\hline 35 & $\begin{array}{l}\text { If I'm sure that Pinocchio reigned for } 3 \text { periods or } \\
\text { maybe for life, then the term "KAFIR" } \\
\text { In the Qur'an alone is able to change its meaning, } \\
\text { especially just to amend the } 1945 \text { constitution } \\
\text { Mah doll is more afraid of the employer than God }\end{array}$ & @Aline_Y_Tan & 5 July 2021 \\
\hline 36 & $\begin{array}{l}\text { For them Corona is just a Chinese hallucination } \\
\text { And Indonesian was crushed by these } \\
\text { hallucinations, hundreds of trillions were spent for } \\
\text { free Without ever being audited... } \\
\text { In this case the Muslim are very much deceived by } \\
\text { this evil regime... }\end{array}$ & @ prisma93246654 & 20 July 2021 \\
\hline
\end{tabular}

\section{b. Discussions}

In this study a number of data will be analyzed using the framework of the discipline of linguistics using a critical discourse analysis approuch and law. The critical discourse analysis approach will reveal data related to hate speech and legal approach that will be used a reference in concluding wheather the data has a criminal impact or not. The following discussion will describe the findings in the form of hate speech against President Joko Widodo which has an impact on criminal law.

\begin{tabular}{|l|l|}
\hline Data 1 & Data Analysis \\
\hline
\end{tabular}




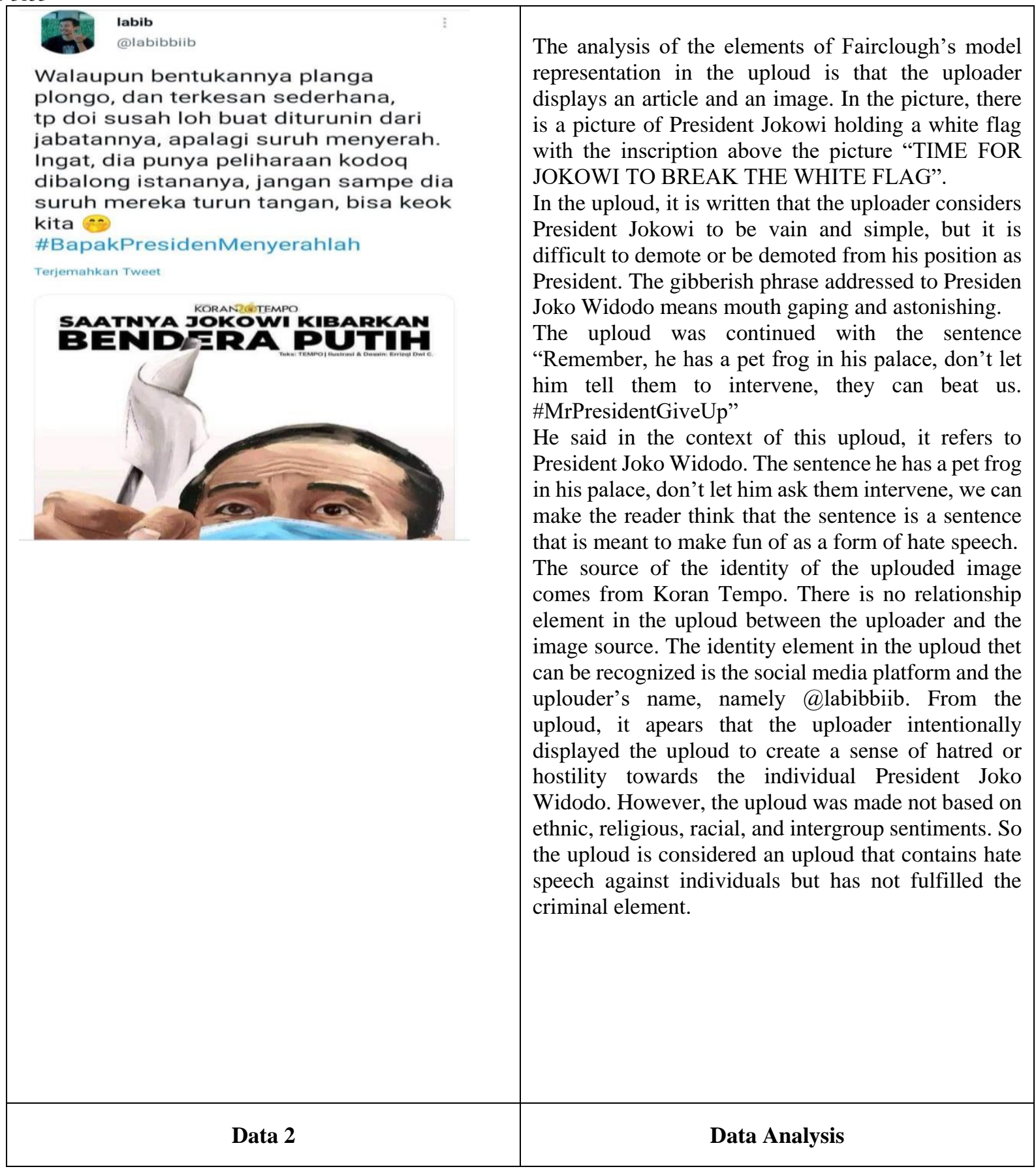


ajikurr $\mathrm{r}$ nya dua

@ajikurr

Membalas @jokowi

Gw jarang misuh ${ }^{2}$ pejabat

pemerintahan, tp kalo ini udah bener ${ }^{2}$

kebangetan TOLOLnya.

Intinya negara ga mau ngasih makan rakyat makanya pake istilah PPKM.

Dan perpanjang sedikit ${ }^{2} \mathrm{krn}$ biar ga

ada demo dimana ${ }^{2}$.

Udah 2 thn tp malah tambah parah.

\section{KIRIK !}

Terjemahkan Tweet

22:21 - 02 Agu 21 - Twitter Web App
The representation element contained in the uploud is that the uplouader displays a text without an image on Twitter social media. In the uplouds was written the sentence "I rarely fight with government officials, but this is really a lot of fun TOLOL." Through a lot of fun." Through his uploud, the account owner said he rarely messed with goverment officials. The word "misuh" in KBBI V means to say goodbye or curse. The word stupid is addressed to the government official of President Joko Widodo. The uploud does not display clear data.

The uploud continued with the sentence "The point is the state doesn't want to feed the people, that's why we use the term PPKM. And it's been extended a little bit because there aren't any demos anywhere. It's been 2 years but it's getting worse. KIRIK/DOG!"

The word Kirik/Dog is a word that means puppy, the word is government officials of President Joko Widodo.

The element of the relationship that occurs is that the uplouader is displayed is about the PPKM policy issue from the government which continues to be extended. The identity element in the post can be recognized from the name of the uplouder and the media used.

By law, the uploud can be linked to the ITE Law. The uplouder's element has been identified, namely the name@ajikurr, the uploud has been proven to contain hate speech for cursing government officials. Legally, the element of intention is carried out, diseminating information is also clearly aimed at the target.

People who do not agree with government policies will certainly hate the government even more. So, the uploud can have legal implications.

\begin{tabular}{|c|}
\hline Data 3 \\
\hline 4.1 Kembali nya Perlawanan \\
@YakinKembali
\end{tabular}

begitulah mental para bedabah. kwalitas berpikir seonggok sampah. tak peduli rakyat tak makan, yg penting mereka sudah. Kelak pengadilan mereka siakhirat tak akan mudah.

\section{\#LunturnyaEmpatiPenguasa}

\section{Terjemahkan Tweet}

dadang rhs@dadangrhs·27 Jul

Menyalahkan rakyat, di tengah wabah, adalah cara mudah pejabat menutupi salah. Watak lama tak pernah berubah.

\#Merawatlngat

1:14 28 Jul $21 \cdot$ Twitter for Android

\section{Data Analysis}

The representation element displayed is an uploud on Twitter in the form of an uploud that comments on other uplouds.

The diction used leads to diction that degrades the mentality and way of thinking of the goverment.

The element of the relationship that occurs is that there is no relationship between the uploader and the upload being commented on.

The identity element of the account cannot be known because the name of the account owner is not written on the account. But uses the account name (a) YakinKembali. The word "bedebah" in the uploud is interpreted as an insult to the goverment. Then continued with the sentence quality of thinking a pile of garbage. These sentences include sentences of hate speech aimed at degrading the goverment's way of thinking. The social media used is known to be Twitter, but the name of the account used is not clear. The element of intentionality can be seen from the sentenced used, so that it can be fully understood that the written criticism contains hate speech. These uplouds can make some people provoked and hate the government. Even if the account name is not clear, this post could have legal repercussions. 


\begin{tabular}{|c|c|}
\hline Data 4 & Data Analysis \\
\hline $\begin{array}{l}\text { Badra_APpz } \\
\text { Gpp pak @jokowi Diperpanjang aja } \\
\text { terus sampe dajjal turun, Imam } \\
\text { Mahdi turun, nabi Isa AS turun, trus } \\
\text { lanjut kiamat } \\
\text { Terjemahkan Tweet } \\
\text { 20:59 · } 02 \text { Agu } 21 \cdot \text { Twitter for Android }\end{array}$ & $\begin{array}{l}\text { The elements of representation depicated is an uploud } \\
\text { on Twitter that displays an article. The language used } \\
\text { is diction which means annoyance and demeaning of } \\
\text { President Joko Widodo's policies. The element of the } \\
\text { relationship that occurs is the absence of a direct } \\
\text { relationship between the uplouder and President Joko } \\
\text { Widodo. The identity element of social media has } \\
\text { been identified, namely Twitter, but the account name } \\
\text { is not clearly known. From the uploud, it can be judged } \\
\text { that the uplouder does not support government } \\
\text { policies. In its entirety, the uploud contains resentment } \\
\text { against President Joko Widodo. } \\
\text { The uplouder element is not clear, the social media } \\
\text { used is clear, namely Twitter. However, this uploud } \\
\text { has no legal effect. }\end{array}$ \\
\hline Data 5 & Data Analysis \\
\hline $\begin{array}{l}\text { @doyan } \\
\text { Tsunami, longsor, gempa bumi, } \\
\text { wedus gembel, memanglah } \\
\text { musibah yg besar, tapi sejarah } \\
\text { akan mencatat Indonesia pernah } \\
\text { mendapatkan musibah yg paling } \\
\text { besar yaitu dipimpin oleh seseorang } \\
\text { yang tidak punya kapasitas } \\
\text { untuk memimpin suatu negara } \\
\text { \#JokowiMusibahBangsa } \\
\text { Terjemahkan Tweet } \\
\text { 22:30·02 Agu 21·Twitter for Android }\end{array}$ & $\begin{array}{l}\text { The element of representation in the uploud is an } \\
\text { uploud on Twitter that displays an article ending with } \\
\text { the hastag \#JokowiMusibahBangsa. The sentence } \\
\text { Tsunami, landslide, earthquake, wedus gembel, are } \\
\text { indeed big disasters, but history will record that } \\
\text { Indonesian has experienced the biggest disaster, which } \\
\text { was led by someone who did not have the capaity to } \\
\text { lead a country. The sentence in its entirety means hate } \\
\text { speech that equates several major disasters with the } \\
\text { individual President Joko Widodo, by saying } \\
\text { President Joko Widodo is a President who does not } \\
\text { have the capacity to lead the country and this is } \\
\text { considered a major disaster. } \\
\text { The element of the relationship that occurs is that there } \\
\text { is no relationship between the uploader and the posts } \\
\text { uploaded. } \\
\text { By Law, the identity element of social media has been } \\
\text { known, namely Twitter. The uploader's account name } \\
\text { is also known, namely @ doyan. Then the uploud was } \\
\text { proven to contain hate speech, was done intentionally, }\end{array}$ \\
\hline
\end{tabular}




\begin{tabular}{|c|c|}
\hline & $\begin{array}{l}\text { and demeaned President Joko Widodo. This uploud } \\
\text { can have a negative impact on the community because } \\
\text { it is able to provoke some people who form the start } \\
\text { are not in line with the government to hate the } \\
\text { goverment even more. Therefore, this upload may } \\
\text { have legal implications. }\end{array}$ \\
\hline Data 6 & Data Analysis \\
\hline 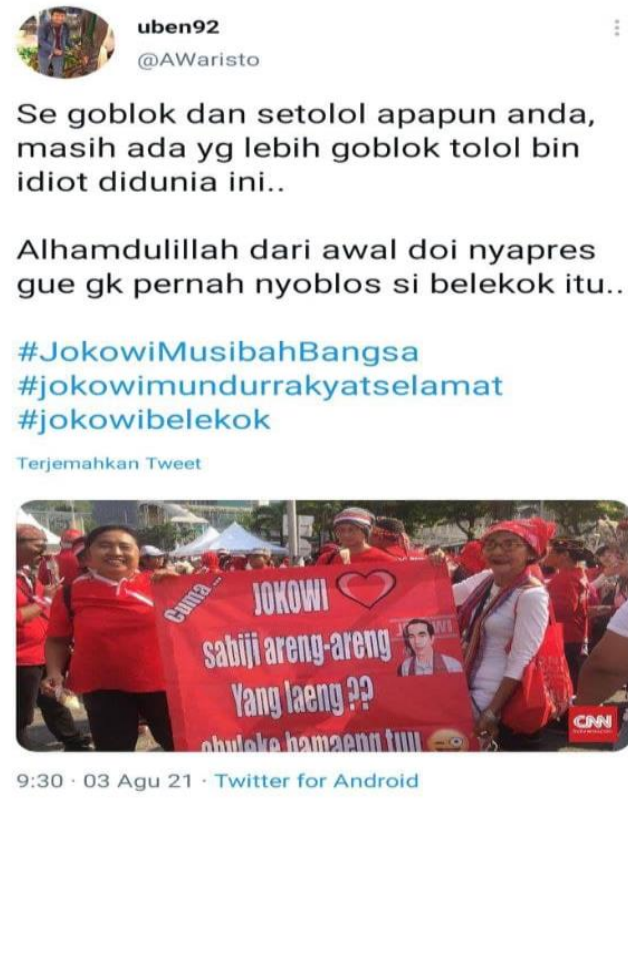 & $\begin{array}{l}\text { The element of representation is an uploud on Twitter } \\
\text { by an account with the name @ Awaristo. } \\
\text { The uploud features text and images. The sentence in } \\
\text { the uploud in its entirety means hate speech against } \\
\text { President Joko Widodo. In addition, the uploud } \\
\text { contains hate speech against the readers of the uploud } \\
\text { by writing the sentence as stupid and as stupid as you } \\
\text { are, the sentence is a hate speech, then continued with } \\
\text { the sentence that there are still more stupid idiots in } \\
\text { this world. This sentence is addressed } \\
\text { To President Joko Widodo. The word stupid is very } \\
\text { stupid/ deaf, and stupid means very stupid. } \\
\text { The element of the relationship that occurs is the } \\
\text { absence of a relationship between the uplouder and the } \\
\text { image. The identity element of the account name is } \\
\text { clear, namely @ Awaristo. So, the uploud is hate } \\
\text { speech. } \\
\text { By law, the uploud is done intentionally, the } \\
\text { information is deliberately aimed at the target. Then } \\
\text { people who are not in line with the government even } \\
\text { more. The post is also very clearly personal attack. } \\
\text { Therefore, the uploud can have legal implications. }\end{array}$ \\
\hline
\end{tabular}

\section{Conclusion}

This study produces several conclusions that can be observed from the explanation above. Uplouds of criticism of President Joko Widodo found on social media Twitter tendto contain post that contain hate speech. From the findings, there are 36 data on hate speech against President Joko Widodo on Twitter social media. These hate speeches tend to be provocative and can create hatred against the government, especially President Joko Widodo. In addition, the diction used in making these uplouds tends to be rude and inappropriate. From a legal perspective, uplouds that are considered hate speech against President Joko Widodo are grouped into three, namely hate speech with the potential to be criminal, hate speech that does not contain a crime, and uplouds that do not contain hate speech and do not contain criminality.

\section{References}

Coulthard, M., \& Johnson, A. “The Routledge Handbook of Forensic Linguistics.” New York: Routledge, 2010. “An Introduction to Forensic Linguistic Language in Evidence.” London and New York: Routledge, 2007.

Fairclough, N. “Critical Discourse Analysis: The Critical of Language.” New York: Longman Publishing, 1995. 
Gelashvili, Teona. “Hate Speech on Social Media: Implications of Private Regulation and Governance Gaps". Sweden: Lund University, 2018.

Gibbons, J., \& Turell, T. “Dimensions of Forensic Linguistics”. Amsterdam: John Benjamins, 2008.

Macdougall, CD (1935). Journalism \& Mass Communication Quarterly, 12 (2), 166-177.

Moeljatno. (1999). The Criminal Code. Jakarta: Earth Literacy.

Olsson, J. (2004). Forensic Linguistics: An Introduction to the Language, Crime and the Law. New York: Cromwell Press.

Sholihatin, Endang. (2019). Forensic Linguistics and Language Crime. Yogyakarta: Student Library.

Shuy, RW. (2006). Linguistics in the Courtroom A Practical Guide. New York: Oxford University Press, Inc.

Law Number 9 of 1998 concerning Freedom to Express Opinions in Public, Article 45 (2).

Articles 156 and 157 of the Criminal Code Law concerning the Spread of Hate, Hostility or Humiliation Among or Against Groups of the Indonesian People.

Law Number 11 of 2008 Concerning Information and Electronic Transactions, Article 28 (2).

\section{Author}

First Author - Dedy Isnanto, Language and Education, Yogyakarta State University, Indonesia; dedyisnanto.2020@student.uny.ac.id

Second Author - Dr. Teguh Setiawan, M.Hum, Language and Education, Yogyakarta State University, Indonesia; teguh.setiawan@uny.ac.id

Correspondence Author - Dedy Isnanto, Language and Education, Yogyakarta State University, Indonesia; dedyisnanto.2020@student.uny.ac.id, +6282246123623 